\title{
Sulfur signature of hydrothermal systems in central Nepal
}

\author{
SANDEEP THAPA ${ }^{1}$, FRÉDÉRIC GIRAULT ${ }^{1}$, DR. JABRANE \\ LABIDI $^{1}$, ELODIE MULLER $^{2}$, DAMIEN DELDICQUE ${ }^{3}$, \\ REMI LOSNO $^{1}$ AND FRÉDÉRIC PERRIER $^{1}$ \\ ${ }^{1}$ Institut de Physique du Globe de Paris \\ ${ }^{2}$ CNRS - IMPMC \\ ${ }^{3}$ École Normale Supérieure \\ Presenting Author: sandeepthapa.geo@gmail.com
}

Resulting from the India-Eurasia collision, the Nepal Himalaya accommodates the shortening by the Main Himalayan Thrust (MHT) décollement ramp. In the vicinity of the Main Central Thrust (MCT) shear zone, a major thrust related to MHT separating Higher Himalayan metamorphic rocks to the north from Lesser Himalayan ones to the south, several hydrothermal systems are present. In the Upper Trisuli valley, located $60 \mathrm{~km}$ north to Kathmandu and encompassing the Langtang, Bhote Koshi, Chilime and Trisuli river systems, numerous hydrothermal systems exhibit hot springs with elevated dissolved sulfate $\left(\mathrm{SO}_{4}{ }^{2-}\right)$ concentrations ( $\left.\max : 2200 \mu \mathrm{M} / \mathrm{L}\right)$. Free gases are dominated by carbon dioxide $\left(\mathrm{CO}_{2}\right)$ with substantial hydrogen sulfide $\left(\mathrm{H}_{2} \mathrm{~S}\right)$ concentration (max: $\left.300 \mathrm{ppm}\right)$. Surrounding rocks include graphitic mica-schists with sulfur-rich minerals ( $c a$. pyrite $\mathrm{FeS}_{2}$ ). Here we present, high spatial resolution sulfur isotope composition $\left(\delta^{34} \mathrm{~S}, \Delta^{33} \mathrm{~S}, \Delta^{36} \mathrm{~S}\right)$ of spring waters $(n>30)$, gaseous $\mathrm{H}_{2} \mathrm{~S}(n=4)$ and graphitic schists $(n>10)$ in the Upper Trisuli valley, central Nepal. Values of $\delta^{34} \mathrm{~S}$ of $\mathrm{SO}_{4}{ }^{2-}$ are heterogeneous and range from $2.8 \pm 1.0 \%$ to $18.9 \pm 1.0 \%$. The lithology appears to control this spatial variability, with higher $\delta^{34} \mathrm{~S}$ values in the Higher Himalaya. At the Syabru-Bensi hydrothermal system, the $\delta^{34} \mathrm{~S}$ values of $\mathrm{H}_{2} \mathrm{~S}$ (mean: $5.94 \pm 0.15$ $\%$ ) are similar to $\delta^{34} \mathrm{~S}$ values of dissolved $\mathrm{SO}_{4}{ }^{2-}$ obtained in nearby hot springs. Values of $\delta^{34} \mathrm{~S}$ of graphitic schists from several outcrops range from $-1.5 \pm 0.5 \%$ to $11 \pm 0.5 \%$ (mean: $3.9 \pm 1.5 \%$ ). This large range of variation may account for the spatial dispersion from the outcrop scale to the geological formation scale. This data-set of the Upper Trisuli valley, Central Nepal is compared with data obtained in other valleys of Nepal, in the vicinity of MCT. Our results suggest pyrite oxidation from graphitic mica-schists at depth may control the sulfur signature of $\mathrm{SO}_{4}{ }^{2-}$ from hot springs in the whole Upper Trisuli valley. This implies an important additional input of sulfur with a high $\delta^{34} \mathrm{~S}$ signature in these river systems, consistent with recent inferences of pyrite oxidation in the Narayani watershed. 